\title{
Identification of Semiochemicals from Cowpea, Vigna unguiculata, for Low-input Management of the Legume Pod Borer, Maruca vitrata
}

\author{
Jonathan Osei-Owusu ${ }^{1}$ • József Vuts ${ }^{2}$. John C. Caulfield ${ }^{2} \cdot$ Christine M. Woodcock $^{2} \cdot$ David M. Withall $^{2}$. \\ Antony M. Hooper ${ }^{3} \cdot$ Samuel Osafo-Acquaah $^{1} \cdot$ Michael A. Birkett $^{2}$ (D)
}

Received: 25 October 2019 /Revised: 2 January 2020 / Accepted: 8 January 2020 / Published online: 17 January 2020

(C) The Author(s) 2020

\begin{abstract}
Cowpea, Vigna unguiculata L. Walp. (Fabaceae), is one of the most important food legumes grown on the African continent, as it provides an affordable source of dietary protein. Yields of cowpea are significantly reduced through damage by legume pod-borer, Maruca vitrata (Lepidoptera: Crambidae), caterpillars to flowers, tender leaves and pods. Semiochemical-based strategies are considered as environmentally benign and affordable for pest management, particularly on smallholder farms. In this study, we investigated the importance of cowpea flower volatiles as host location cues for egg-laying M. vitrata, and herbivore-induced plant volatiles (HIPVs) as M. vitrata repellents and natural enemy (Apanteles taragamae and Phanerotoma syleptae parasitoid) attractants. In oviposition choice assays, $M$. vitrata laid more eggs on flowering cowpea plants than non-flowering plants. Coupled gas chromatography-electrophysiology (GC-EAG) analysis using the antennae of female $M$. vitrata and an extract of flower volatiles collected by dynamic headspace collection revealed the presence of five EAG-active components that were identified by coupled GCmass spectrometry (GC-MS) analysis as benzaldehyde, benzyl alcohol, acetophenone, a vinylbenzaldehyde isomer and $(E)$ cinnamaldehyde. A synthetic blend of the identified compounds, prepared using 3-vinylbenzaldehyde, induced $M$. vitrata to lay as many eggs on non-flowering cowpea as on flowering plants. The moths also preferred laying eggs on intact plants compared to M. vitrata-infested plants. As the emission of EAG-active floral compounds was determined to be lower in the headspace of infested cowpea flowers, the role of HIPVs emitted by $M$. vitrata-damaged leaves was also investigated. Of the compounds induced by larval damage, $(E)$-DMNT, indole, n-hexyl acetate, 1-octen-3-ol and linalool were shown by GC-EAG to possess electrophysiological activity. A synthetic blend of the EAG-active compounds, using racemic 1-octen-3-ol and linalool, significantly reduced egg numbers on flowering cowpea. Larval and egg parasitoids, i.e. A. taragamae and Ph. syleptae, respectively, of $M$. vitrata both preferred the Ytube olfactometer arm treated with synthetic $(E)$-DMNT, whereas preference for racemic linalool and $(E)$-nerolidol was dose-dependent in A. taragamae. Our results provide the platform for the development of future semiochemical-based pest management strategies against M. vitrata on smallholder farms in West Africa.
\end{abstract}

Keywords Cowpea $\cdot$ Vigna unguiculata $\cdot$ Legume pod borer $\cdot$ Maruca vitrata $\cdot$ Semiochemicals $\cdot$ Natural enemies $\cdot$ IPM

Electronic supplementary material The online version of this article (https://doi.org/10.1007/s10886-020-01149-7) contains supplementary material, which is available to authorized users.

Michael A. Birkett

mike.birkett@rothamsted.ac.uk

1 Department of Chemistry, Kwame Nkrumah University of Science and Technology, Kumasi, Ghana

2 Biointeractions and Crop Protection Department, Rothamsted Research, Harpenden AL5 2JQ, UK

3 School of Biological and Chemical Sciences, Queen Mary University of London, London, UK

\section{Introduction}

Cowpea, Vigna unguiculata L. Walp. (Fabaceae), is one of the most important food legumes grown on the African continent, as it provides an affordable source of dietary protein (AddoQuaye et al. 2011; Agyeman et al. 2014). The grain contains about $25 \%$ protein and $64 \%$ carbohydrate (FAO, 2004), and provides a source of minerals, vitamins and essential micronutrients (Boukar et al. 2013; Togola et al. 2017). However, crop yields remain very low, which is mainly due to biotic and abiotic factors including pest insects, diseases, parasitic weeds, drought and low soil fertility (Singh and Jackai 1985). The legume pod-borer, Maruca vitrata 
Fabricius (syn. M. testulalis Geyer) (Lepidoptera: Pyralidae), negatively affects the production of cowpea and other legumes not just in sub-Saharan Africa, but also in Asia and Latin America (Sharma et al. 1999). Larval feeding damage to cowpea plants occurs on flower buds, flowers, seed pods, tender leaves and terminal shoots, and losses in grain yield of $20-80 \%$ have been estimated from infestation by this pest alone (Sharma et al. 1999; Singh et al. 1990; Machuka et al. 1999). The cryptic feeding habit of the larvae protects them from contact insecticides, which then often results in insecticide overuse and the subsequent development of insecticide resistance (Downham et al. 2004; Ekesi 1999). Alternative leguminous host plants of $M$. vitrata include Sesbania cannabina (Retz.) Pers., which can adapt well to drought, water logging, high alkalinity, metal toxicity, and is used as a green manure crop to help fix atmospheric nitrogen (Funakoshi et al. 2015; Huang et al. 2003; Nitisha 2014).

In search of non-insecticidal-based strategies for $M$. vitrata management, breeding resistant cowpea varieties with traits affecting pod wall thickness, trichomes, nutritional and antibiotic content has been attempted, but to date, no cowpea line has been identified to possess the desired levels of resistance to the pest (Fatokun et al. 2002). A transgenic cowpea variety expressing the Bt-protein CrylAb against $M$. vitrata already exists, but is unavailable for use by African farmers (Oyewale and Bamaiyi 2013). More sustainable, low-input management strategies include the deployment of semiochemicals that $M$. vitrata uses to find suitable hosts, mates, oviposition substrates, or to escape competition and natural enemies, and avoid toxic plant defense chemicals. The female sex pheromone components of $M$. vitrata have been identified as (E,E)-10,12-hexadecadienal, $(E, E)$-10,12-hexadecadienol and $(E)$-10-hexadecenal, and are used for monitoring populations (Adati and Tatsuki 1999; Downham et al. 2004; Schläger et al. 2015). Although the synthetic pheromone blend can attract $11-50 \%$ females of the total catch (Downham et al. 2004), the female ratio could be further increased to provide more precise forecasts for the timing of egglaying (Wall 1989). Because volatile cues from the larval host can be key for ovipositing insects to locate suitable plants (Städler 1994), cowpea volatile blends serve as potent kairomones for host-seeking $M$. vitrata. Feng et al. (2017) found $(E)-(1 R, 9 S)$-caryophyllene to induce egg-laying on cowpea, and Wang et al. (2014) described the blend of limonene, 1,3diethylbenzene, 4-ethylbenzaldehyde and 4-ethylacetophenone as an attractant for females.

When used concurrently, attractive and repellent volatile blends can enhance the effectiveness of semiochemicalbased management strategies (e.g. Hassemer et al. 2019). Volatiles from conspecific-infested host plants can be the source of such repellent compounds, as demonstrated in the case of Heliothis virescens Fabr. (Lepidoptera: Noctuidae) (De Moraes et al. 2001), for example, where egg-laying females were repelled by the blend of their host plant, Nicotiana tabacum L. (Solanaceae), released in response to feeding by conspecific caterpillars. Furthermore, natural enemies of the pest can also utilize herbivore-induced plant volatiles (HIPVs) as kairomones to locate prey (e.g. Aartsma et al. 2017). The prospect of biological control with the solitary larval endoparasitoid Apanteles taragamae Viereck (Hymenoptera: Braconidae), which is capable of parasitising on average $63 \%$ of $M$. vitrata larvae on S. cannabina (Huang et al. 2003), led to studies on exploiting this natural enemy for biological control of $M$. vitrata feeding on cowpea (Dannon et al. 2010). Also, another braconid, the egg parasitoid Phanerotoma syleptae Zettel, was recently introduced into Benin from Asia for the control of $M$. vitrata (Srinivasan et al. 2015). In view of the potential for using host-derived semiochemicals for insect pest management, the aims of the current work were four-fold: 1) to identify volatile compounds from cowpea that attract $M$. vitrata for egg-laying; 2) to identify HIPVs from cowpea that repel egg-laying $M$. vitrata; 3 ) to identify HIPVs produced by $S$. cannabina in response to $M$. vitrata larval feeding and compare them with HIPVs from cowpea; and 4) to assess olfactory responses of the parasitic wasps A. taragamae and Ph. syleptae to selected cowpea HIPVs. Characterization of semiochemicals that deter the pod borer or induce a change in cowpea defence status to attract parasitoids would provide the basis for novel $M$. vitrata management strategies on smallholder farms using either synthetic or plantderived attractants and repellents.

\section{Methods and Materials}

\section{Plants}

Seeds of the Ghanaian cowpea cultivar Padi-tuya were obtained from the Savanna Agriculture Research, Tamale, Ghana. One seed per pot $(9 \times 9 \times 10 \mathrm{~cm})$ was grown in a greenhouse at Rothamsted Research, UK $\left(27{ }^{\circ} \mathrm{C}: 25^{\circ} \mathrm{C}\right.$ and 16:8 h L:D photoperiod, LED lighting) in soil ( $\mathrm{pH} 5.5-6.0$; $75 \%$ mediumgrade peat, $12 \%$ sterilised loam, $3 \%$ medium-grade vermiculite; $10 \% 5 \mathrm{~mm}$ lime-free grit; $<2 \mathrm{~mm}$ particle size after sieving). Seeds of $S$. cannabina were provided by the International Institute of Tropical Agriculture (IITA), Benin, for experimental use. One seed per pot $(20 \times 30 \mathrm{~cm})$ was grown in heatsterilized loamy soil at $36{ }^{\circ} \mathrm{C}: 23{ }^{\circ} \mathrm{C}$ and $12: 12 \mathrm{~h} \mathrm{~L}: \mathrm{D}$ photoperiod in a greenhouse at the Kwame Nkrumah University of Science and Technology (KNUST), Kumasi, Ghana.

\section{Insects}

Maruca vitrata colonies were reared at KNUST at $26^{\circ} \mathrm{C}$, with a photoperiod of 12:12 L:D and $76 \%$ relative humidity. Fiveday-old, mated adult females were transferred into transparent cylindrical plastic cups $(3 \mathrm{~cm}$ diameter $\times 3.5 \mathrm{~cm}$ height $)$ for 
oviposition for $48 \mathrm{~h}$, and kept on $10 \%$ honey solution on a piece of filter paper. Cups with eggs were subsequently incubated in a large plastic container with sprouting cowpea grains as feeding substrate for newly hatched larvae, which were replaced with new grains every three days until pupation. Pupae were collected from the diet after 15 days and were placed inside a netted cage under similar conditions for emergence. Fifth instar larvae of $M$. vitrata were transported to Rothamsted Research, UK, where they were placed in open petri dishes with artificial diet, prepared according to Jackai and Raulston (1988) and provided by IITA, Nigeria [400 g cowpea flour, $127.2 \mathrm{~g}$ wheatgerm, $44.4 \mathrm{~g}$ Wesson salt mix, $25 \mathrm{~g}$ ascorbic acid, $3.9 \mathrm{~g}$ aureomycin, $60 \mathrm{~g}$ sugar, $3.6 \mathrm{~g}$ methyl $p$-hydroxybenzoate, $6.8 \mathrm{~g}$ sorbic acid, $2 \mathrm{~L}$ water, $22 \mathrm{~mL}$ potassium hydroxide (4 M aq. solution), $29.6 \mathrm{~mL}$ choline chloride (15\%), $50 \mathrm{~mL}$ acetic acid (25\%), $26 \mathrm{~mL}$ formaldehyde (10\%), $30 \mathrm{~mL}$ vitamin suspension and $59.2 \mathrm{~g}$ agar] and kept in a netted cage at $25^{\circ} \mathrm{C}: 22{ }^{\circ} \mathrm{C}$ and 12:12 h L:D photoperiod. Emerged adults were fed with $10 \%$ sugar solution. After five days, mated females were isolated in groups of two in transparent plastic cups for two days for oviposition. Cups with eggs were placed on artificial larval diet. A colony of the larval endoparasitoid Apanteles taragamae was started by obtaining cocoons from a stock culture maintained at IITA, Benin. Subsequent colonies were produced by exposing first instar M. vitrata caterpillars (two days old) to parasitization by 3day-old female A. taragamae for $24 \mathrm{~h}$. Parasitized caterpillars were reared on sprouting cowpea grains until pupation. Cocoons of A. taragamae were collected from the sprouting diet after seven days of parasitism and were placed inside a netted cage for emergence. Emerge adults were fed with honey solution streaked inside the cage. Cocoons of the egg parasitoid Phanerotoma syleptae were also obtained from IITA, Benin. Emerged adults were fed with honey solution streaked inside the walls of the rearing cage. To allow mated wasps to parasitize hosts, $M$. vitrata eggs in small cylindrical cups ( $3 \mathrm{~cm}$ diameter $\times 3.5 \mathrm{~cm}$ height) were offered to 2-day-old mated P. syleptae females. Parasitized larvae were reared on sprouting cowpea diet as described above.

\section{Collection of Volatiles by Dynamic Headspace Sampling (Air Entrainment)}

Plant material was enclosed in glass vessels and connected with a charcoal-cleaned air source (Capillary-Grade Hydrocarbon Trap with 1/8 in. compression fittings; Thames Restek Ltd., High Wycombe, UK), supplying an inflow of $700 \mathrm{~mL} / \mathrm{min}$, which was then drawn through a Porapak Q trap (50 mg polymer load, 50/80 mesh, Supelco, Bellefonte, $\mathrm{PA}$ ) at $600 \mathrm{~mL} / \mathrm{min}$ at the air outlet $\left(\mathrm{T}=22^{\circ} \mathrm{C}\right.$; Pye volatile collection kits, Kings Walden, UK). Prior to use, glass vessels and metal plates were washed with detergent (Teepol), acetone and distilled water, and baked overnight at $140{ }^{\circ} \mathrm{C}$. Porapak Q tubes were conditioned before use by washing with $4 \mathrm{~mL}$ distilled diethyl ether and heating at $132{ }^{\circ} \mathrm{C}$ under a stream of nitrogen. Adsorbed volatiles were eluted from the polymer by washing with $750 \mu \mathrm{L}$ of redistilled diethyl ether and then concentrated to $50 \mu \mathrm{L}$ under a gentle stream of nitrogen gas. The experiments were replicated four times. Intact plants and empty glass chambers served as control.

\section{Collection of Cowpea Volatiles from Flowers}

Two cowpea flowers were enclosed in a glass vessel $(100 \mathrm{~mm}$ i.d. $\times 60 \mathrm{~mm}$ height) attached to semicircular aluminum plates around the plant stem, and air entrainment was run for $24 \mathrm{~h}$. For the infestation experiment, two M. vitrata larvae (2nd instar) were carefully placed on two cowpea flowers at night. The larvae were then given $30 \mathrm{~min}$ to settle before entraining the flowers for $24 \mathrm{~h}$.

\section{Collection of Volatiles from Leaves of Cowpea and S. cannabina}

For the isolation of HIPVs, ten 2 nd/3rd instar larvae were placed on the tender leaves of two-to-three-week-old cowpea plants with no flowers. Each of the plants was then enclosed in a glass vessel $(95 \mathrm{~mm} \mathrm{i.d} \times 210 \mathrm{~mm}$ height), the bottom of which fitted around the plant stem by using two semicircular aluminum plates with a hole in the centre. To simulate the effect of mechanical damage during caterpillar feeding on cowpea volatile emission, five holes per leaf were made on three leaves of a cowpea plant, using a standard A4 paper hole punch, imitating the extent of damage caused by $M$. vitrata caterpillars. Air entrainments started immediately after the mechanical damage and ran for $6 \mathrm{~h}$. For S. cannabina, leaves of three-week-old plants were infested with ten $M$. vitrata larvae (2nd instar), enclosed as above, and HIPVs collected for $72 \mathrm{~h}$.

\section{Coupled Gas Chromatography (GC) -Electroantennography (GC-EAG)}

Electrophysiological responses from the antennae of 5-day-old mated female $M$. vitrata moths to extracts of cowpea leaf volatiles were recorded using coupled GC-electrophysiology (Wadhams 1990). A moth was immobilized by chilling on ice, one of its antennae removed and the tip of the last segment cut off to ensure a good contact. The excised antenna was then mounted between two glass capillary electrodes filled with ringer solution ( $7.55 \mathrm{~g} / \mathrm{L}$ sodium chloride, $0.64 \mathrm{~g} / \mathrm{L}$ potassium chloride, $0.22 \mathrm{~g} / \mathrm{L}$ calcium chloride, $1.73 \mathrm{~g} / \mathrm{L}$ magnesium chloride, $0.86 \mathrm{~g} / \mathrm{L}$ sodium bicarbonate, $0.61 \mathrm{~g} / \mathrm{L}$ sodium orthophosphate). Antennal signals were passed through a UN-06 high-impedance amplifier (Ockenfels Syntech GmbH, Germany). Separation of the volatiles collected from cowpea was achieved on an Agilent $6890 \mathrm{~N}$ GC (Agilent Technologies), equipped with a cool on-column 
injector and a flame ionization detector (FID), using a $50 \mathrm{~m} \times$ $0.32 \mathrm{~mm}$ i.d., $0.52 \mu \mathrm{m}$ film thickness HP- 1 column. The oven temperature was maintained at $30^{\circ} \mathrm{C}$ for $2 \mathrm{~min}$ and then programmed at $5^{\circ} \mathrm{C} / \mathrm{min}$ to $250^{\circ} \mathrm{C}$. The carrier gas was helium. The outputs from the EAG amplifier and the FID were monitored simultaneously and analysed using a customised software package (Syntech GC/EAD for Windows v 2.3 09/1997). One $\mu \mathrm{L}$ aliquots of the pooled volatile samples were analyzed. A compound was identified as EAG-active if it evoked an antennal response in all of the three coupled runs for both the flower and leaf headspace extracts.

\section{GC Analysis and Coupled GC-Mass Spectrometry (GC-MS)}

Volatile extracts were analyzed on a GC (Agilent Technologies, $6890 \mathrm{~N}$, Stockport, UK), equipped with an FID and a HP-1 capillary column $(50 \mathrm{~m} \times 0.32 \mathrm{~mm}$ i.d., $0.52 \mu \mathrm{m}$ film thickness). The oven temperature was maintained at $30{ }^{\circ} \mathrm{C}$ for $1 \mathrm{~min}$ and programmed at $5{ }^{\circ} \mathrm{C} / \mathrm{min}$ to $150{ }^{\circ} \mathrm{C}$, where it was held for $0.1 \mathrm{~min}$, then at $10^{\circ} \mathrm{C} / \mathrm{min}$ to $230^{\circ} \mathrm{C}$ and held for $27 \mathrm{~min}$. The carrier gas was hydrogen. One $\mu \mathrm{L}$ of sample was injected into the injection port of the equipment manually. GC-MS analysis of eluted volatiles was performed using a Waters Autospec Ultima mass spectrometer couple to an Agilent 6890 GC fitted with a HP-1 capillary column $(50 \mathrm{~m} \times 0.32 \mathrm{~mm}$ id, $0.52 \mu \mathrm{m}$ film thickness $)$. Ionization was by electron impact $(70 \mathrm{eV}$, source temperature $220^{\circ} \mathrm{C}$ ). Helium was the carrier gas. The oven temperature was maintained at $30^{\circ} \mathrm{C}$ for $5 \mathrm{~min}$, and then programmed at $5{ }^{\circ} \mathrm{C} / \mathrm{min}$ to $250{ }^{\circ} \mathrm{C}$. Tentative identifications were made by comparison of mass spectra with NIST 2005 mass spectral database. Confirmation of peak identity was made by comparison of their Kováts index (KI) values and GC peak enhancement with authentic compounds. Compounds were quantified using the single point external method with an n-alkane $\left(\mathrm{C}_{7^{-}}\right.$ $\mathrm{C}_{22}$ ) mixture. Statistical analysis of cowpea volatile data (ng/ h) was done using two-sample $t$-test on log-transformed values (GenStat version 16).

\section{Chemicals}

Benzyl alcohol (99\%) was obtained from Sigma-Aldrich, USA. (E)-Nerolidol (analytical standard), (E)-cinnamaldehyde (99\%), acetophenone (99\%), 3-vinylbenzaldehyde (97\%), benzaldehyde (99\%), (Z)-3-hexenyl acetate (>95\%), (E)-2-hexenal (98\%), (Z)3-hexen-1-ol (98\%), n-hexyl acetate (99\%), (RS)-limonene (97\%), methyl salicylate (99\%), decanal (97\%), myrcene (analytical standard) were purchased from Sigma-Aldrich, UK. (RS)1-Octen-3-ol (98\%) was obtained from Alfa Aesar, UK, $(R S)$ linalool (97\%) was from Fluka, Switzerland, and indole (99\%) was from Avocado Research Chemicals, UK. (E)-Ocimene was synthesized via the synthetic route previously reported from our group (Hassemer et al. 2016). Nonanal and decanal were purified by dissolving one gram of each compound in pentane $(20 \mathrm{~mL})$ and washing three times with saturated $\mathrm{NaHCO}_{3}$ solution. The organic layer was dried $\left(\mathrm{MgSO}_{4}\right)$ and concentrated under vacuum to yield the purified compounds. $(E)-4,8$ Dimethyl-1,3,7-nonatriene[(E)-DMNT)] was synthesized as below. To a solution of geraniol $(1.00 \mathrm{~g}, 6.48 \mathrm{mmol})$ in dichloromethane $(20 \mathrm{~mL})$ was added freshly prepared manganese dioxide $(2.82 \mathrm{~g}, 32.40 \mathrm{mmol})$ and the mixture stirred for $24 \mathrm{~h}$. The mixture was diluted with dichloromethane $(20 \mathrm{~mL})$, filtered through celite and concentrated under vacuum to give geranial $(0.96 \mathrm{~g}, 97 \%$ yield $)$ as a colourless oil. ${ }^{1} \mathrm{H}-\mathrm{NMR}\left(\mathrm{CDCl}_{3}\right.$, $500 \mathrm{MHz}): \delta 10.01(\mathrm{~d}, 1 \mathrm{H}, J=8.1 \mathrm{~Hz}, \mathrm{CHO}), 5.90(\mathrm{~d}, 1 \mathrm{H}$, $J=8.1 \mathrm{~Hz}, \mathrm{CHOCH}), 5.09\left(\mathrm{t}, 1 \mathrm{H}, J=6.7 \mathrm{~Hz},(\mathrm{Me})_{2} \mathrm{C}=\mathrm{CH}\right)$, 2.27-2.21 (m, 4H), 2.19 (s, 3H, CHOCH=C(Me)), $1.71(\mathrm{~s}, 3 \mathrm{H}$, $\left.(\mathbf{M e})_{2} \mathrm{C}=\mathrm{CH}\right), 1.63\left(\mathrm{~s}, 3 \mathrm{H},(\mathbf{M e})_{2} \mathrm{C}=\mathrm{CH}\right) ;{ }^{13} \mathrm{C}-\mathrm{NMR}\left(\mathrm{CDCl}_{3}\right.$, $125 \mathrm{MHz}): \delta 191.35,163.90,132.96,127.43,122.57,40.62$, $25.74,25.67,17.74,17.60$. To a solution of methyl triphenylphosphonium bromide $(2.81 \mathrm{~g}, 7.85 \mathrm{mmol})$ in THF $(30 \mathrm{~mL})$, cooled to $0{ }^{\circ} \mathrm{C}$ under $\mathrm{N}_{2}$, was added $n$-butyl lithium $(5.1 \mathrm{~mL}$, $8.24 \mathrm{mmol}$ ) and the solution allowed to warm to RT over $60 \mathrm{~min}$. The mixture was cooled to $-78{ }^{\circ} \mathrm{C}$ before geranial $(0.96 \mathrm{~g}, 6.28 \mathrm{mmol})$ in THF $(10 \mathrm{~mL})$ was added. After stirring for $60 \mathrm{~min}$, the mixture was allowed to warm to RT over $16 \mathrm{~h}$. Diethyl ether $(40 \mathrm{~mL})$ was added and the mixture cooled to $-20{ }^{\circ} \mathrm{C}$ for a further $30 \mathrm{~min}$. The suspension was filtered through celite, the precipitate washed with ice-cold diethyl ether and the combined organic filtrates concentrated under vacuum. The crude product was purified on silica gel (100\% pet ether) to give $(E)$-DMNT $(0.92 \mathrm{~g}, 97 \%$ yield $)$ as a colourless oil. ${ }^{1} \mathrm{H}-$ NMR $\left(\mathrm{CDCl}_{3}, 500 \mathrm{MHz}\right): \delta 6.61\left(\mathrm{~m}, 1 \mathrm{H}, \mathrm{H}_{2} \mathrm{C}=\mathrm{CH}\right), 5.89(\mathrm{~d}$, $\left.1 \mathrm{H}, J=11.0 \mathrm{~Hz}, \mathrm{H}_{2} \mathrm{C}=\mathrm{CHCH}\right), 5.13(\mathrm{~m}, 2 \mathrm{H}), 5.01(\mathrm{~d}, 1 \mathrm{H}, J=$ $\left.10.4 \mathrm{~Hz}, \mathbf{H}_{2} \mathrm{C}=\mathrm{CH}\right), 2.14(\mathrm{~m}, 2 \mathrm{H}), 2.10(\mathrm{~m}, 2 \mathrm{H}), 1.80(\mathrm{~s}, 3 \mathrm{H}$, $\left.\mathrm{H}_{2} \mathrm{C}=\mathrm{CHCHC}(\mathbf{M e})\right), 1.71\left(\mathrm{~s}, 3 \mathrm{H},(\mathbf{M e})_{2} \mathrm{C}=\mathrm{CH}\right), 1.64(\mathrm{~s}, 3 \mathrm{H}$, $\left.(\mathbf{M e})_{2} \mathrm{C}=\mathrm{CH}\right) ;{ }^{13} \mathrm{C}-\mathrm{NMR}\left(\mathrm{CDCl}_{3}, 125 \mathrm{MHz}\right): \delta 139.58$, $133.44,131.74,125.40,123.95,114.57,39.88,26.52,25.72$, $17.70,16.68$. (E)- $\beta$-Farnesene was synthesized as below. To a solution of $(E, E)$-farnesol $(1.00 \mathrm{~g}, 4.5 \mathrm{mmol})$ and 3,4dihydropyran $(1.89 \mathrm{~g}, 22.50 \mathrm{mmol})$ in dichloromethane $(30 \mathrm{~mL})$ was added $p$-toluenesulfonic acid $(86 \mathrm{mg}, 0.45 \mathrm{mmol})$, and the mixture was stirred for $60 \mathrm{~min}$. The reaction mixture was diluted with dichloromethane before being washed with water, sat $\mathrm{NaHCO}_{3}$, dried $\left(\mathrm{MgSO}_{4}\right)$ and concentrated under vacuum. The crude product was purified on silica gel $(4 \%$ $\mathrm{Et}_{2} \mathrm{O}$ in pet ether) to give THP-farnesol $(1.10 \mathrm{~g}, 80 \%$ yield $)$ as a colourless oil. ${ }^{1} \mathrm{H}-\mathrm{NMR}\left(\mathrm{CDCl}_{3}, 500 \mathrm{MHz}\right): \delta 5.39(\mathrm{~m}$, $\left.1 \mathrm{H}, \mathrm{OCH}_{2} \mathrm{CH}=\mathrm{C}\right), 5.12(\mathrm{~m}, 2 \mathrm{H}), 4.65\left(\mathrm{~m}, 1 \mathrm{H}, \mathrm{OC}\left(\mathrm{CH}_{2}\right) \mathbf{H O}\right)$, $4.26\left(\mathrm{dd}, 1 \mathrm{H}, \mathrm{OCH}_{2} \mathrm{CH}=\mathrm{C}, J_{1}=11.9\right.$ and $\left.6.4 \mathrm{~Hz}\right), 4.05(\mathrm{dd}$, $1 \mathrm{H}, \mathrm{OCH}_{2} \mathrm{CH}=\mathrm{C}, J=11.9$ and $\left.7.5 \mathrm{~Hz}\right), 3.92(\mathrm{~m}, 1 \mathrm{H}$, $\left.\mathrm{OCH}_{2} \mathrm{CH}_{2}\right), 3.53\left(\mathrm{~m}, 1 \mathrm{H}, \mathrm{OCH}_{2} \mathrm{CH}_{2}\right), 2.15-2.00(\mathrm{~m}, 8 \mathrm{H})$, $1.84(\mathrm{~m}, 1 \mathrm{H}), 1.74(\mathrm{~m}, 1 \mathrm{H}), 1.71(\mathrm{~m}, 6 \mathrm{H}), 1.62-1.54(\mathrm{~m}$, 9H); ${ }^{13} \mathrm{C}-\mathrm{NMR}\left(\mathrm{CDCl}_{3}, 125 \mathrm{MHz}\right): \delta 140.33,135.27$, $131.35,124.35,123.91,120.57,97.81,63.67,62.31,39.66$, 
$30.74,26.74,26.31,25.73,25.52,19.65,17.71,16.45,16.04$. To a solution of THP-farnesol $(1.10 \mathrm{~g}, 3.59 \mathrm{mmol})$ and 18crown-6 (190 mg, $0.72 \mathrm{mmol}$ ), under $\mathrm{N}_{2}$, was added potassium $t$-butoxide $(4.03 \mathrm{~g}, 35.90 \mathrm{mmol})$ and the reaction heated to $65{ }^{\circ} \mathrm{C}$ for $16 \mathrm{~h}$. The reaction mixture was cooled to RT before being diluted with pet ether, washed with water, sat $\mathrm{NaHCO}_{3}$, dried $\left(\mathrm{MgSO}_{4}\right)$ and concentrated under vacuum. The crude product was purified on fluorosil $(100 \%$ pet ether) to give (E)- $\beta$-farnesene $(0.69 \mathrm{~g}, 95 \%$ yield $)$ as a colourless oil. ${ }^{1} \mathrm{H}$ NMR $\left(\mathrm{CDCl}_{3}, 500 \mathrm{MHz}\right): \delta 6.41\left(\mathrm{dd}, 1 \mathrm{H}, \mathrm{H}_{2} \mathrm{C}=\mathrm{CHC}, J=\right.$ 17.7 and $10.8 \mathrm{~Hz}), 5.28\left(\mathrm{~d}, 1 \mathrm{H}, \mathbf{H}_{2} \mathrm{C}=\mathrm{CHC}, J=17.7 \mathrm{~Hz}\right)$, $5.19(\mathrm{~m}, 1 \mathrm{H}, \mathrm{RC}(\mathrm{Me})=\mathrm{CH}), 5.13\left(\mathrm{~m}, 1 \mathrm{H},(\mathrm{Me})_{2} \mathrm{C}=\mathrm{CH}\right)$, $5.09\left(\mathrm{~d}, 1 \mathrm{H}, \mathbf{H}_{2} \mathrm{C}=\mathrm{CHC}, J=10.9 \mathrm{~Hz}\right), 5.04(\mathrm{~m}, 2 \mathrm{H}$, $\mathrm{H}_{2} \mathrm{C}=\mathrm{CHC}\left(\mathrm{CH}_{2}\right), 2.28-2.19(\mathrm{~m}, 4 \mathrm{H}), 2.10(\mathrm{~m}, 2 \mathrm{H}), 2.02(\mathrm{~m}$, $2 \mathrm{H}), 1.71(\mathrm{~s}, 3 \mathrm{H}), 1.63(\mathrm{~m}, 6 \mathrm{H}) ;{ }^{13} \mathrm{C}-\mathrm{NMR}\left(\mathrm{CDCl}_{3}, 125 \mathrm{MHz}\right)$ : $\delta 146.21,139.03,135.37,131.23,124.39,124.05,115.55$, $112.96,39.69,31.49,26.74,26.67,25.61,17.62,15.98)$.

\section{Synthetic Blend Formulation}

Synthetic blends of EAG-active compounds required for oviposition assays were formulated into polyethylene vial dispensers $(6 \mathrm{~mm}$ i.d. $\times 37 \mathrm{~mm}$ height, $1 \mathrm{~mm}$ wall thickness; Just Plastics, UK) with a piece of cotton bud (ca. $0.125 \mathrm{~cm}^{3}$ ). The ratios of neat compounds administered onto the cotton buds were based on their ratios in volatile extracts as determined by GC-FID. Amounts of compounds used for the floral blend formulation in each dispenser were: benzaldehyde $10.0 \mathrm{mg}$, benzyl alcohol $0.4 \mathrm{mg}$, acetophenone $5.0 \mathrm{mg}, 3$-vinylbenzaldehyde $0.8 \mathrm{mg}$, $(E)$-cinnamaldehyde $4.0 \mathrm{mg}$. Amounts of compounds used for the HIPV blend formulation in each dispenser were: $(E)$-DMNT $9.5 \mathrm{mg}, \mathrm{n}$-hexyl acetate $0.4 \mathrm{mg}$, indole $0.3 \mathrm{mg},(R S)$-linalool $0.4 \mathrm{mg},(R S)$-1-octen-3-ol $0.3 \mathrm{mg}$. Formulated dispensers were entrained over periods of $3 \mathrm{~h}$ and $48 \mathrm{~h}$ in glass chambers $(100 \mathrm{~mm}$ i.d. $\times$ $60 \mathrm{~mm}$ height) at $22{ }^{\circ} \mathrm{C} / 50 \% \mathrm{RH}$ and extracts analyzed by GC-FID to determine emission rates. The release rate of the synthetic blends: benzaldehyde $11.13 \mathrm{ng} / \mathrm{h}$, benzyl alcohol $3.4 \mathrm{ng} / \mathrm{h}$, acetophenone $5.23 \mathrm{ng} / \mathrm{h}, 3-$ vinylbenzaldehyde $6.76 \mathrm{ng} / \mathrm{h},(E)$-cinnamaldehyde $4.46 \mathrm{ng} / \mathrm{h}$; and (E)-DMNT $2308.37 \mathrm{ng} / \mathrm{h}, \mathrm{n}$-hexyl acetate $142.86 \mathrm{ng} / \mathrm{h}$, indole $194.33 \mathrm{ng} / \mathrm{h},(R S)$-linalool $184.03 \mathrm{ng} /$ h, $(R S)$-1-octen-3-ol $190.03 \mathrm{ng} / \mathrm{h}$.

\section{Oviposition Assays}

To assess oviposition preferences of female $M$. vitrata, dualchoice experiments were carried out in netted cages $(120 \times$ $90 \times 90 \mathrm{~cm})$ in a greenhouse at KNUST $(12: 12 \mathrm{~h} \mathrm{~L}: \mathrm{D}$, temperature $34: 23{ }^{\circ} \mathrm{C} \mathrm{L}: \mathrm{D}$, humidity 47:78\% L:D). In each replicate of each experiment, ten 5-day-old mated female moths were released into the cages. For the first set of oviposition experiments, moths were offered a choice between a flowering and a non-flowering (3-weeks old) cowpea plant $(n=5)$. In the second set of oviposition experiments, moths were offered a choice between an intact flowering plant and one fed upon by ten 3 rd instar M. vitrata larvae (larvae remained on the infested plant during the experiment) $(n=$ 13). In the third set of oviposition experiments, the choice between a non-flowering cowpea plant plus the synthetic floral blend and an intact flowering plant was offered. The synthetic floral blend was loaded into the dispenser vial, and the lure was mounted on a small wooden stick in the same plant pot $(n=6)$. For the fourth set of oviposition assays, the choice between a flowering cowpea plant plus the HIPV blend and an intact flowering plant was offered. The synthetic HIPV blend was loaded into the dispenser vial, which was mounted on a small wooden stick in the same plant pot $(n=11)$. The number of eggs laid on each plant after $48 \mathrm{~h}$ was counted and analyzed by Mann-Whitney U test (twotailed, $\alpha=0.05)($ GenStat version 16).

\section{Parasitoid Behaviour Assays}

Responses of A. taragamae and P. syleptae to selected identified compounds produced both by damaged cowpea and S. cannabina plants were investigated using a glass Y-tube olfactometer $(16 \mathrm{~mm}$ i.d $\times 50 \mathrm{~mm} \times 60 \mathrm{~mm})$ (B. J. Pye, Kings Walden, UK). Air, purified by passing through an activated carbon filter at a flow rate of $3 \mathrm{~L} /$ min, was divided in two and each air stream passed through the odour sources administered onto filter paper inside a connector, and then into the olfactometer arms. A fluorescent lamp was placed above the olfactometer at a height of $40 \mathrm{~cm}$ to provide uniform lighting. Threeday-old naive mated females of A. taragamae and 2day-old naive mated females of $P$. syleptae were introduced individually at the side entry of the olfactometer, and their responses to odour treatments monitored for 10 min. Female wasps not moving away for about $5 \mathrm{~min}$ from the release point were discarded. Twenty replications of each test compound at each dose were done with A. taragamae, and 50 replications with $P$. syleptae. The position of the odour treatment was altered after every five replications to eliminate any bias in the experimental setup. Parasitoids that did not move up to $1 / 3$ of the chosen arm were considered as nonresponders and were not included in the statistical analysis. Differences between the number of parasitoids choosing the control (hexane) and the treated arm were tested by chi-square test, with the null hypothesis that the distribution of wasps over the two arms of the ytube olfactometer was 50:50 (R Development Core Team 2018). 


\section{Results}

\section{Vitrata Oviposition Attractants}

Female moths laid more eggs on flowering cowpea plants than on non-flowering ones (medians: flowering plants: 320 , nonflowering plants: 31; Mann-Whitney $U=0.0, \mathrm{n}_{1}=\mathrm{n}_{2}=5, p=$ 0.008) (Fig. 1a). As it was hypothesized that floral volatiles attract ovipositing moths to larval food plants, cowpea flower headspace extracts were analyzed by coupled GC-electrophysiology (GCEAG), using female moth antennae. Five peaks elicited consistent antennal responses, which were identified by coupled GCMS and GC peak enhancement as benzaldehyde, benzylalcohol, acetophenone, a vinylbenzaldehyde isomer and $(E)$ cinnamaldehyde (Supplementary Fig. 1). A synthetic blend of these compounds (using commercially available 3vinylbenzaldehyde) rendered non-flowering cowpea plants as attractive for ovipositing female moths as flowering plants (medians: flowering plants 150.5 , treated plants 92; Mann-Whitney $U=15.0, \mathrm{n}_{1}=\mathrm{n}_{2}=6, p=0.699$ ) (Fig.1c).

\section{Vitrata Oviposition Repellents}

In behavioural assays, the number of eggs laid on uninfested flowering plants was higher than that on plants infested by conspecific larvae (medians: uninfested plants: 275, infested plants 110; Mann-Whitney $U=6.0, \mathrm{n}_{1}=\mathrm{n}_{2}=13, p<0.001$ ) (Fig. 1b). GC analysis revealed that infested flowers emitted the same compounds as intact ones, but in lower quantities, except the vinylbenzaldehyde isomer (Table 1). However, GC-EAG analysis of headspace extracts of infested leaves located electrophysiologically active peaks, which were subsequently identified as $(R$ or $S$ )-1-octen-3-ol, $n$-hexyl acetate, $(R$ or $S$ )-linalool, $(E)$-DMNT and indole (Supplementary Fig. 1). When intact flowering cowpea plants were treated with a synthetic blend of these HIPVs, females laid fewer eggs on treated plants than on flowering plants (medians: flowering plants 161, treated plants 71; Mann-Whitney $U=17.0, \mathrm{n}_{1}=$ $\mathrm{n}_{2}=11, p=0.003$ ) (Fig.1d). Mechanical damage to leaves caused the induction of (E)-2-hexenal, (Z)-3-hexen-1-ol and (Z)-3-hexenyl acetate, but not of the compounds induced by caterpillar feeding (Table 2). The volatile profile of $S$. cannabina plants infested by $M$. vitrata larvae showed similarities to that of infested cowpea plants, including the emission of 1-octen-3-ol, $(E)$-ocimene, linalool, $(E)$-DMNT, methyl salicylate, indole and (E)-nerolidol (Table 2).

\section{Parasitoid Responses to Synthetic Compounds}

Three-day-old mated female $A$. taragamae wasps did not choose the olfactometer arm treated with any doses of $(E)$-ocimene over the hexane control (Fig. 2). However, they responded positively to $(R S)$-linalool applied at doses of $0.05,0.1,1$ and $10 \mu \mathrm{g}$, but not at $0.01 \mu \mathrm{g}$. Positive responses to $(E)$-nerolidol at doses of 1 and $10 \mu \mathrm{g}$, but not at $0.1,0.05$ and $0.01 \mu \mathrm{g}$, were recorded. $(E)$ DMNT at doses of 0.1 and $10 \mu \mathrm{g}$ was preferred by wasps to the hexane control, however, they did not discriminate between (E)-DMNT and the control at $1,0.05$ and $0.01 \mu \mathrm{g}$ doses. Female $P$. syleptae wasps did not respond positively to $(E)$-ocimene, $(E)$ nerolidol and $(R S)$-linalool when exposed to $1 \mu \mathrm{g}$ of each compound in the Y-tube olfactometer. However, there was a significant preference for (E)-DMNT (Fig. 3).

\section{Discussion}

In this study, we confirmed female $M$. vitrata. oviposition preference for host, ie. cowpea, plants, at the generative (flowering) stage. Wang et al. (2014) showed that a synthetic blend of nine EAG-active volatile compounds identified from
Fig. 1 Mean $( \pm$ SEM) number of eggs laid a) on flowering and nonflowering cowpea plants in cage choice bioassays $(n=5)$; b) on intact flowering cowpea plants and on those infested by M. vitrata larvae $(n=13)$; c) on flowering cowpea plants and on non-flowering plants treated with a blend of synthetic floral volatiles $(n=6) ; \mathrm{d})$ on flowering cowpea plants and on flowering plants treated with a blend of synthetic HIPVs $(n=11)$
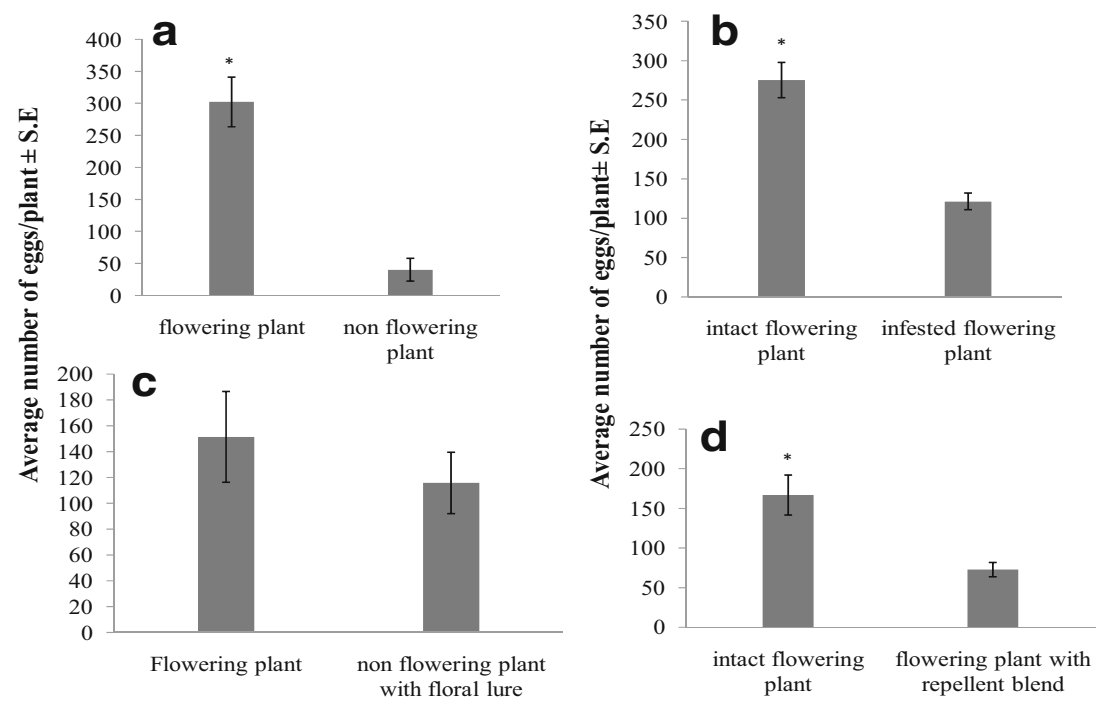
Table 1 Mean ( \pm SEM) amounts (ng/day) of volatiles released by intact and $M$. vitrata caterpillar-infested cowpea flowers (Vigna unguiculata $\mathrm{v}$. Padi-tuya) $(n=4) . P$ values from two-sample $t$-test

\begin{tabular}{llll}
\hline Compound & Intact flower & Infested flower & $P$ value \\
\hline Benzaldehyde & $0.254 \pm 0.062$ & $0.011 \pm 0.001$ & $<0.001$ \\
Benzyl alcohol & $0.005 \mathrm{e} \pm 0.003$ & $0.00033 \pm 0.0003$ & 0.048 \\
Acetophenone & $0.095 \pm 0.032$ & $0.005 \pm 0.003$ & 0.008 \\
Vinylbenzaldehyde isomer & $0.011 \pm 0.005$ & $0.011 \pm 0.007$ & 0.998 \\
$(E)$-Cinnamaldehyde & $0.113 \pm 0.028$ & $0.013 \pm 0.001$ & 0.001 \\
\hline
\end{tabular}

cowpea flowers elicited attraction from $M$. vitrata females in wind tunnel bioassays. Apart from benzaldehyde and acetophenone, composition of their synthetic floral blend differed from that described here, probably because Wang et al. (2014) used a different cowpea cultivar. Coupled GCEAG analysis in our study located physiologically active components in flower headspace extracts of the Padi-tuya cultivar, and bioassays showed that a synthetic blend of compounds comprising benzaldehyde, benzylalcohol, acetophenone, 3vinylbenzaldehyde and $(E)$-cinnamaldehyde made flowerless plants just as attractive to ovipositing $M$. vitrata as flowering plants. This suggests that the mixture of these floral volatiles can be used as an olfactory cue by $M$. vitrata to locate host plants for oviposition and larval development. The blend constituents are widespread floral compounds in angiosperms (Knudsen et al. 2006) and attractive to many insects (e.g. Lohonyai et al. 2019; Beck et al. 2012; Tóth et al. 2011), whereas a vinylbenzaldehyde isomer different from the one in this study has been isolated from N. tabacum and found to be electrophysiologically active on a particular type of olfactory receptor neuron of Helicoverpa armigera Hübner and H. virescens (Lepidoptera: Noctuidae) (Røstelien et al. 2005).

Florivory can negatively affect plant reproductive success (McCall and Irwin 2006), and altered volatile profiles may change the dynamics of plant-pollinator interactions (LucasBarbosa et al. 2011). However, only a few studies have determined the emission of floral volatiles after flower damage by herbivores. For example, damage to flowers of Pastinaca sativa L. (Apiaceae) by Depressaria pastinacella Duponchel (Lepidoptera: Elachistidae) causes increase in the quantity of floral compounds emitted, particularly octyl esters (Zangerl and Berenbaum 2009). In contrast, we observed a significant decrease in overall floral volatile emission after florivory by $M$. vitrata larvae. As $M$. vitrata is not a cowpea pollinator, such a response may make cowpea
Table 2 Mean ( \pm SEM) amounts (ng/day) of volatiles released by intact, $M$. vitrata caterpillarinfested and mechanically damaged cowpea (Vigna unguiculata v. Padi-tuya) plants $(\mathrm{n}=4)$, as well as intact and $M$. vitrata caterpillar-infested Sesbania cannabina plants $(n=3)$. (E)DMNT $=(E)-4,8$-Dimethyl1,3,7-nonatriene. Dashes indicate the absence of a compound. $\mathrm{KI}=$ Kováts index

\begin{tabular}{|c|c|c|c|c|c|c|}
\hline \multirow[t]{2}{*}{ Compound } & \multirow[t]{2}{*}{$\mathrm{KI}^{\mathrm{a}}$} & \multicolumn{3}{|c|}{ V. unguiculata } & \multicolumn{2}{|l|}{ S. cannabina } \\
\hline & & Intact & $\begin{array}{l}\text { Caterpillar- } \\
\text { infested }\end{array}$ & $\begin{array}{l}\text { Mechanical } \\
\text { damage }\end{array}$ & Intact & $\begin{array}{l}\text { Caterpillar- } \\
\text { infested }\end{array}$ \\
\hline (E)-2-Hexenal & 823 & - & $0.011 \pm 0.002$ & $0.026 \pm 0.014$ & - & - \\
\hline (Z)-3-Hexen-1-ol & 841 & - & $0.041 \pm 0.020$ & $0.131 \pm 0.033$ & - & - \\
\hline$(R$ or $S)$-1-Octen-3-ol & 964 & - & $0.024 \pm 0.001$ & - & - & $0.109 \pm 0.033$ \\
\hline Myrcene & 983 & - & $0.054 \pm 0.023$ & - & - & - \\
\hline (Z)-3-Hexenyl acetate & 987 & - & $0.199 \pm 0.018$ & $0.352 \pm 0.131$ & - & - \\
\hline$n$-Hexyl acetate & 996 & - & $0.017 \pm 0.007$ & - & - & - \\
\hline$(R$ or $S$ )-Limonene & 1024 & - & $0.030 \pm 0.010$ & - & - & - \\
\hline (E)-Ocimene & 1041 & - & $0.014 \pm 0.001$ & - & - & $0.098 \pm 0.04$ \\
\hline Nonanal & 1084 & - & - & - & $0.098 \pm 0.011$ & $0.088 \pm 0.021$ \\
\hline$(R$ or $S$ )-Linalool & 1083 & - & $0.023 \pm 0.004$ & - & - & $1.904 \pm 0.674$ \\
\hline (E)-DMNT & 1106 & - & $0.715 \pm 0.359$ & - & - & $2.714 \pm 0.994$ \\
\hline Methyl salicylate & 1171 & - & $0.010 \pm 0.001$ & - & - & $0.157 \pm 0.08$ \\
\hline Decanal & 1185 & - & - & - & $0.097 \pm 0.004$ & $0.047 \pm 0.023$ \\
\hline Indole & 1252 & - & $0.050 \pm 0.015$ & - & - & $2.024 \pm 0.955$ \\
\hline (E)- $\beta$-Farnesene & 1450 & - & $0.170 \pm 0.037$ & - & - & - \\
\hline (E)-Nerolidol & 1551 & - & $0.022 \pm 0.005$ & - & - & $0.232 \pm 0.078$ \\
\hline$\beta$-Sesquiphellandrene ${ }^{\mathrm{b}}$ & 1442 & - & $0.147 \pm 0.046$ & - & - & - \\
\hline$(Z)-\beta$-Farnesene ${ }^{\mathrm{b}}$ & 1452 & - & - & - & - & $0.096 \pm 0.016$ \\
\hline Linalool oxide $^{\mathrm{b}, \mathrm{c}}$ & 1061 & - & - & - & - & $0.057 \pm 0.036$ \\
\hline
\end{tabular}

${ }^{\mathrm{a}}$ on a non-polar GC column (HP-1)

${ }^{\mathrm{b}}$ Tentative identification by GC-MS

${ }^{\mathrm{c}}$ furanoid 


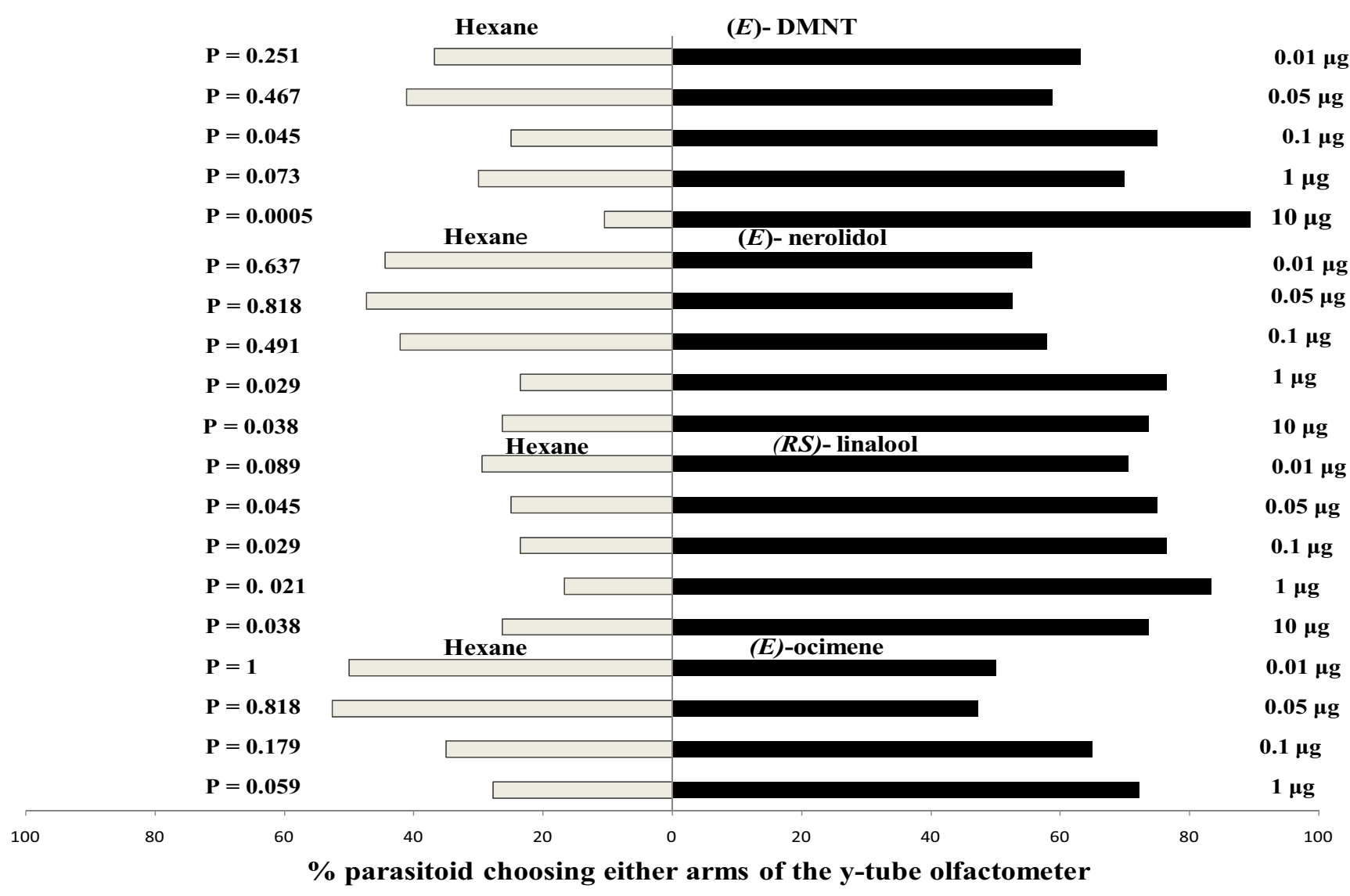

Fig. 2 Behavioural responses of 3-day-old naive mated female A. taragamae to different doses of synthetic $(E)$-ocimene, $(E)$-nerolidol, $(R S)$-linalool and (E)-DMNT in Y-tube olfactometer bioassays. $N=20$

plants less apparent to ovipositing moths, thus reducing further damage to generative organs and preserving fitness of the individual. Kessler et al. (2019) showed that floral volatile emissions can be context-dependent: benzylacetone

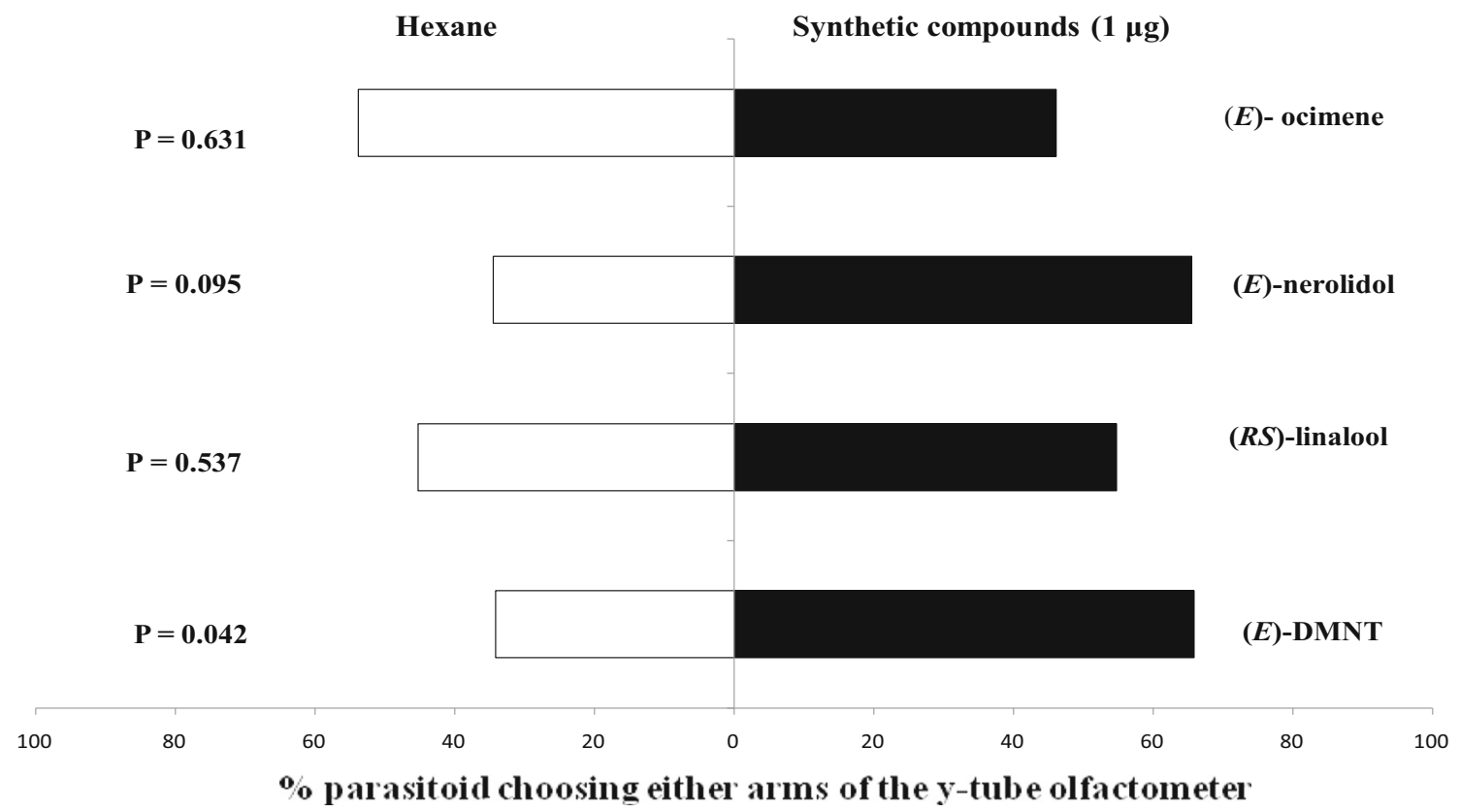

Fig. 3 Behavioural responses of naive mated female P. syleptae to synthetic $(E)$-ocimene, $(E)$-nerolidol, $(R S)$-linalool and $(E)$-DMNT in Y-tube olfactometer bioassays. $N=50$ 
attracts key pollinators (hawkmoths) of $N$. attenuata Torr ex $S$. Watson, but repels florivores (a leaf beetle species).

$M$. vitrata larvae not only feed on generative organs, but also on tender leaves and terminal shoots of cowpea (Bendera et al. 2015; Sharma et al. 1999). When five-day-old mated $M$. vitrata females were presented with a choice between non-infested flowering cowpea plants and those infested by conspecific larvae, moths preferred to lay eggs on noninfested ones. GC analysis of leaf headspace extracts of infested plants revealed enhanced levels of fifteen compounds. Of these, a synthetic blend of the electrophysiologically active $(E)$-DMNT, indole, n-hexyl acetate, $(R S)$-1-octen3 -ol and $(R S)$-linalool reduced oviposition rates on flowering cowpea, indicating that the blend was repellent. Tissue damage by pest insects often stimulates the release of herbivoreinduced plant volatiles (HIPVs) that can deter further herbivore attack (Turlings and Erb 2018). De Moraes et al. (2001) observed that $H$. virescens moths were repelled by HIPVs from their larval host and argued that this recognition of HIPVs may reduce negative fitness consequences posed by competitors. In another study, when transgenic $N$. tabacum plants, which produced high amounts of linalool, and nontransformed control plants where presented to $H$. armigera for oviposition, fewer eggs were laid on transgenic plants, suggesting a repellent role for linalool (McCallum et al. 2011). Anastasaki et al. (2018) showed that Tuta absoluta Meyrick (Lepidoptera: Gelechiidae) females preferred to oviposit on healthy tomato (Solanum lycopersicum L.) (Solanaceae) plants as opposed to those infested by conspecific larvae, and assigned EAG activity to some of the induced volatiles. In our studies, $(E)$-DMNT was the most abundant compound collected from damaged cowpea leaves, which was also reported to be the major cowpea leaf volatile constituent upon infestation by Spodoptera frugiperda J. E. Smith (Lepidoptera: Noctuidae) (Carroll et al. 2008). Interestingly, in this case, $S$. frugiperda moths were attracted by conspecificinduced plant volatiles, especially DMNT, which highlights the fact that HIPVs play different roles in different plant-insect interactions, i.e. the effect of plant volatiles is contextdependent (He et al. 2019).

The observed difference in the leaf volatile profile between plants damaged by $M$. vitrata caterpillars and mechanically damaged ones highlights the role of herbivoreassociated elicitors in inducing volatile emission patterns (Bonaventure et al. 2011). When cowpea leaves were fed upon by $M$. vitrata larvae, the emission of fifteen volatiles was induced, whereas mechanical damage only caused the enhanced emission of $(E)$-2-hexenal, $(Z)$-3-hexen-1-ol and (Z)-3-hexenyl acetate. Thus, it is highly likely that elicitors in the oral secretion of $M$. vitrata caterpillars are introduced into the feeding wounds, which then results in the upregulation of production of a range of compounds. The identity of such elicitors remains to be revealed.
HIPVs can not only repel the herbivores themselves, but can also attract their natural enemies, such as parasitic wasps (Turlings and Erb 2018). For example, the push/pull system in maize in East Africa utilizes a cropping regime, where trap plants on the perimeter lure maize pests (Lepidoptera: Noctuidae) away from the main crop by means of attractive semiochemicals, whereas intercropped plants repel the moths and attract their parasitoids via a suite of volatile terpenes (Khan et al. 2008). De Moraes et al. (2001) argue that HIPV blends are not only utilized by certain herbivorous insects to avoid competitors at oviposition sites, but also to avoid potential attack by natural enemies attracted by the same volatile blend. Of the parasitoids of M. vitrata, Dannon et al. (2010) showed that $A$. taragamae, a solitary endoparasitoid, preferred volatiles from $M$. vitrata-infested cowpea plants, as compared to blank air, in olfactometer bioassays, although the compounds mediating this interaction were not determined. The preference of this parasitic wasp for the odour of infested plants has also been investigated in the context of another host species (Nurkomar et al. 2017). Similarly, Souna et al. (2019) demonstrated the attraction of Therophilus javanus Bhat \& Gupta (Hymenoptera: Braconidae) to the odour of $M$. vitrata caterpillar-damaged cowpea flowers and pods.

As A. taragamae is reported to parasitize $63 \%$ of $M$. vitrata larvae feeding on S. cannabina (Huang et al. 2003), we examined the behavioural response of this wasp to four synthetic semiochemicals produced by both cowpea and S. cannabina upon $M$. vitrata infestation. In general, wasps responded most sensitively to $(R S)$-linalool and $(E)$-DMNT in a positive manner, followed by $(E)$-nerolidol, whereas $(E)$-ocimene was not active in these tests. P. syleptae, an egg parasitoid of $M$. vitrata, only showed preference for (E)-DMNT, although the four synthetic compounds were tested only at a single dose. These indicate that the two parasitoids potentially exploit host-related HIPVs to locate M. vitrata caterpillars and eggs. In the case of the egg parasitoid, P. syleptae may search for caterpillar feeding sites by means of HIPVs, where it has a greater chance of finding host eggs on non-infested neighbouring plants. Alternatively, M. vitrata egg deposition may induce the release of HIPVs, including (E)-DMNT, as part of the cowpea plant's response to herbivore attack, a phenomenon described from maize landraces (Tamiru et al. 2011). The above four compounds not only elicit antennal responses from parasitic wasps in other plant-herbivore systems (Gouinguene et al. 2005), but also attract them (e.g. Kos et al. 2013; Krugner et al. 2014; Li et al. 2018).

\section{Conclusion}

In summary, the work in this study has demonstrated that floral volatiles guide host-searching $M$. vitrata females to cowpea plants for oviposition, whereas the volatile blend 
emitted after caterpillar feeding repels ovipositing moths. Also, certain constituents of the repellent blend are behaviourally preferred by natural enemies of $M$. vitrata, indicating they may be attractive. Therefore, the synthetic blends have the potential to be incorporated in future IPM strategies to reduce $M$. vitrata damage in cowpea by both repelling moths out of the main crop and attracting them to trap crops/into traps, as well as manipulating the density of natural enemies around/within the crop for biological control. To demonstrate the suitability of these semiochemicals for $M$. vitrata management, further assays comparing the activity of synthetic blends with live plants, followed by field trials testing different formulations, will be necessary.

Acknowledgements Funding for this research was provided by the Royal Society-Leverhulme Trust Africa Award (AA110026). The work at Rothamsted Research forms part of the Smart Crop Protection (SCP) strategic programme (BBS/OS/CP/000001) funded through Biotechnology and Biological Sciences Research Council's Industrial Strategy Challenge Fund. The authors wish to thank Manuele Tamò and Benjamine Datinon for the supply of the two parasitoids.

Open Access This article is licensed under a Creative Commons Attribution 4.0 International License, which permits use, sharing, adaptation, distribution and reproduction in any medium or format, as long as you give appropriate credit to the original author(s) and the source, provide a link to the Creative Commons licence, and indicate if changes were made. The images or other third party material in this article are included in the article's Creative Commons licence, unless indicated otherwise in a credit line to the material. If material is not included in the article's Creative Commons licence and your intended use is not permitted by statutory regulation or exceeds the permitted use, you will need to obtain permission directly from the copyright holder. To view a copy of this licence, visit http://creativecommons.org/licenses/by/4.0/.

\section{References}

Aartsma Y, Bianchi F, Werf W, Poelman E, Dicke M (2017) Herbivoreinduced plant volatile and tritrophic interactions across spatial scales. New Phytol 216:1054-1063

Adati T, Tatsuki S (1999) Identification of the female sex pheromone of the legume pod borer, $M$ vitrata and antagonistic effects of geometrical isomers. J Chem Ecol 25:105-115

Addo-Quaye AA, Darkwa A, Ampiah MKP (2011) Performance of three cowpea ecological zones of the central region of Ghana: grain yield and its components. J Agri Bio Sci 6(2):34-42

Agyeman K, Berchie JN, Osei-Bonsu I, Tetteh Nartey E, Fordjour JK (2014) Growth and yield performance of improved cowpea (Vigna unguiculata L.) varieties in Ghana. Agric. Sci 2(4):44-52

Anastasaki E, Drizou F, Milonas P (2018) Electrophysiological and Oviposition responses of Tuta absoluta females to herbivoreinduced volatiles in tomato plants. J Chem Ecol 44:288-298

Beck JJ, Higbee BS, Light DM, Gee WS, Merrill GB, Hayash JM (2012) Hull split and damaged almond volatiles attract male and female navel orange worm moths. J Agric Food Chem 60:8090-8096

Bendera M, Ekesi S, Ndung M, Srinivasan R, Torto B (2015) A major host plant volatile, 1-octen-3-ol, contributes to mating in the legume pod borer, Maruca vitrata (Fabricius) (Lepidoptera: Crambidae). Naturwissenschaften, Sci Nat 102:47
Bonaventure G, Vandoorn A, Baldwin IT (2011) Herbivore-associated elicitors: FAC signaling and metabolism. Trends Plant Sci 16:294-299

Boukar O, Bhattacharjee R, Fatokun C, Kumar LP, Gueye B (2013) Cowpea. In: Singh M, Upadhyaya HD, Bisht IS (eds) Genetic and genomic resources of grain legume improvement. Newnes. Elsevier, New York

Carroll MJ, Schmelz EA, Peter EA (2008) The attraction of Spodoptera frugiperda neonates to cowpea seedlings is mediated by volatiles induced by conspecific Herbivory and the elicitor Inceptin. J Chem Ecol 34:291-300

Dannon E, Tamò M, Arnold VH, Dicke M (2010) Effects of volatiles from Maruca vitrata larvae and Caterpillar-infested flowers of their host plant Vigna unguiculata on the foraging behavior of the parasitoid Apanteles taragamae. J Chem Ecol 36:1083-1091

De Moraes CM, Mescher MC, Tumlinson JH (2001) Caterpillar-induced nocturnal plant volatiles repel nonspecific females. Nature 410:577-580

Downham MCA, Tamò M, Hall DR, Datinon B, Adetonah S, Farman DI (2004) Developing pheromone traps and lures for Maruca vitrata in Benin, West Africa. Entomol Exp Appl 110:151-158

Ekesi S (1999) Insecticide resistance in field population of the legume pod-borer, Maruca vitrata on cowpea in Nigeria. Int J Pest Manag 45(1):57-59

Fatokun CA, Tarawali SA, Singh BB, Kormawa PM, Tamò M (2002) Challenges and opportunities for enhancing sustainable cowpea production. Proceedings of the world cowpea conference III held at the International Institute of Tropical Agriculture (IITA), Ibadan, Nigeria

Feng B, Qian K, Du YJ (2017) Floral volatiles from Vigna unguiculata are olfactory and gustatory stimulants for Oviposition by the bean pod borer moth Maruca vitrata. Insects 8(2):60

Food and Agriculture Organisation (FAO) (2004) Cowpea: Post- harvest operations [online]. Available from< http://www.fao.org/3/a-au994e.pdf

Funakoshi Y, Daimon H, Matsumura A (2015) Formation of densely branched lateral roots in Sesbania cannabina triggered by patchily distributed phosphorus in andosolic soils. Plant Root 9:24-33

Gouinguene S, Pickett J, Lester J, Birkett M, Turlings T (2005) Antennal electrophysiological responses of three parasitic wasps to caterpillarinduced volatiles from maize, cotton and cowpea. J Chem Ecol 31: $1023-1038$

Hassemer MJ, Sant'Ana J, Borges M, Withall D, Pickett JA, de Oliveira MWM, Laumann RA, Birkett MA, Blassioli-Moraes MC (2016) Revisiting the male-produced aggregation pheromone of the lesser mealworm, Alphitobius diaperinus (Coleoptera, Tenebrionidae): identification of a six-component pheromone from a Brazilian population. J Agric Food Chem 64:6809-6818

Hassemer M, Borges M, Withall D, Pickett J, Laumam R, Birkett M, Blassioli-Moraes M (2019) Development of pull and push-pull systems for management of lesser meal worm, Alphitobius diaperinus, in poultry houses using alarm and aggregation pheromones. Pest Manag Sci. https://doi.org/10.1002/ps.5225

He J, Fandino RA, HalitschkeR LK, Köllner TG, Murdock MH, Ray R, Gase K, Knaden M, Baldwin IT, Schuman M (2019) An unbiased approach elucidates variation in $(S)-(+)$-linalool, a context-specific mediator of a tri-trophic interaction in wild tobacco. Proc Natl Acad Sci U S A. https://doi.org/10.1073/pnas.1818585116

Huang CC, Peng WK, Talekar NS (2003) Parasitoids and other natural enemies of Maruca vitrata feeding on Sesbania cannabina in Taiwan. Biol Control 48(4):407-416

Jackai LEN, Raulston JR (1988) Rearing the legume pod borer, Maruca testulalis Geyer (Lepidoptera: Pyralidae) on artificial diet. Trop Pest Manag 34:168-172

Kessler D, Bing J, Haverkamp A, Baldwin I (2019) The defensive function of a pollinator-attracting floral volatile. Func Ecol. https://doi. org/10.1111/1365-2435.13332

Khan ZR, Midega CAO, Wadhams LJ, Pickett JA, Mumuni A (2008) Evaluation of Napier grass (Pennisetum purpureum) varieties for use as trap plants for the management of African stemborer 
(Busseolafusca) in a push-pull strategy. Entomol Expe Appl 124: 201-211

Knudsen JT, Eriksson R, Gershenzon J, Stahl B (2006) Diversity and distribution of floral scent. Bot Rev 72:1-120

Kos M, Houshyani B, Overeem AJ, Bouwmeester HJ, Weldegergis BT, Van Loon JA, Dicke M, Vet L (2013) Genetic engineering of plant volatile terpeniods; effects on a herbivore, a predator and a parasitoid. Pest Manag Sci 69:302-311

Krugner R, Wallis C, Walse S (2014) Attraction of egg parasitoid, Gonatocerus ashmeadi Girault to synthetic formulation of $(E)-\beta$ ocimene and $(E, E)-\alpha$-farnesene mixture. Biol Control 77:23-28

Li F, Li W, Lin YJ, Pickett JA, Birkett MA, Wu K, Wang G, Zhou JJ (2018) Expression of lima bean terpene synthases in rice enhances recruitment of a beneficial enemy of a major rice pest. Plant Cell Envi 41:111-120

Lohonyai Z, Vuts J, Kárpáti Z, Koczor S, Domingue MJ, Fail J, Birkett MA, Tóth M, Imrei Z (2019) Benzaldehyde: an alfalfa-related compound for the spring attraction of the pest weevil Sitona humeralis (Coleoptera: Curculionidae). Pest Manag Sci. https://doi.org/10.1002/ps.5431

Lucas-Barbosa D, van Loon A, Dicke M (2011) The effects of herbivoreinduced plant volatiles on interactions between plants and flowervisiting insects. Phytochem:72, 1647

Machuka JE, Van Damme JM, Peumans WJ, Jackai LEN (1999) Effects of plant lectins on the development of the legume podborer, Maruca vitrata. Entomol Exp Appl 93:179-186

McCall AC, Irwin RE (2006) Florivory: the intersection of pollination and herbivory. Ecol Lett 9:1351-1365

McCallum EJ, Cunningham JP, Lücker J, Zalucki MP, De Voss JJ, Botella JR (2011) Increased plant volatile production affects oviposition, but not larval development, in the moth Helicoverpa armigera. J Exp Bio 214:3672-3677

Nitisha S (2014) Taxonomic characterisation and economic importance of lesser known green manure crop Sesbania cannabina. Int Res J Biol Sci 3:85-88

Nurkomar I, Buchori D, Taylor D, Kainoh Y (2017) Innate olfactory responses of female and male Apanteles taragamaeViereck (Hymenoptera: Braconidae) toward host plant infested by the cucumber moth Diaphania indica Saunders (Lepidoptera: Crambidae). Biocon Sci Tech 27:1373-1382

Oyewale RO, Bamaiyi LJ (2013) Management of Cowpea Insect Pests. J Biosci 1(5):217-226

R Core Team (2018) R: a language and environment for statistical computing. R Foundation for Statistical Computing, Vienna

Røstelien TM, Stranden AK, Borg K, Mustaparta H (2005) Olfactory receptor neurons in two Heliothine moth species responding selectively to aliphatic green leaf volatiles, aromatic compounds, Monoterpenes and Sesquiterpenes of plant origin. Chem Senses 30:443-461

Schläger S, Beran F, Groot AT, Ulrichs C, Veit D, Paetz C, Karumuru BR, Srinivasan R, Schreiner M, Mewis I (2015) Pheromone blend analysis and cross-attraction among populations of Maruca vitrata from Asia and West Africa. J Chem Ecol 41(12):1155-1162

Sharma HC, Saxena KB, Bhagwat VR (1999) The legume podborer, Maruca vitrata: bionomics and management. ICRISAT-Inform Bull 55:37

Singh SR, Jackai LEN (1985) Insect pests of cowpea in Africa; Their life cycle, economic importance, and potential for control. In: Cowpea Research, Production, and Utilization. Singh, S.R. and Rachie, K.O. (Eds.), 217-231

Singh SR, Jackai LEN, Adalla CB (1990) Insect pests of cowpea. In: insect pests of food legumes, edited by S.R. Singh. John Wiley and Sons Ltd, Nigeria. 43-89

Souna DA, Bokonon-Ganta AH, Dannon EA, Imorou N, Agui B, Cusumano A, Srinivasan R, Pittendrigh B, Tamò M (2019) Volatiles from Maruca vitrata (Lepidoptera,Crambidae) host plants influence olfactory responses of the parasitoid Therophilus javanus Hymenoptera, Braconidae, Agathidinae. Biol Con 130:104-109

Srinivasan R, Yule S, Lin MY, Khumsuwan C (2015) Recent developments in the biological control of legume pod borer (Maruca vitrata) on yard-long bean. Acta Hortic 1102:143-150

Städler E (1994) Oviposition behavior of insects influenced by chemoreceptors. In: Kurihara K, Suzuki N, Ogawa H (eds) Olfaction and taste XI. Springer, Tokyo

Tamiru A, Bruce TJA, Woodcock CM, Caulfield CJ, Midega CAO, Ogol CKPO, Mayon P, Birkett MA, Pickett JA, Khan ZR (2011) Maize landraces recruit egg and larval parasitoids in response to egg deposition by a herbivore. Ecol Lett 14:1075-1083

Togola A, Boukar O, Belko N (2017) Host plant resistance to insect pests of cowpea (Vigna unguiculata L. Walp.): achievements and future prospects. Euphytica 213:239

Tóth M, Furlan L, Szarukán I, Vuts J (2011) Development of a femaletargeted attractant for the click beetle Agriotes ustulatus Schwarz. Acta Phytopathologica et Entomologica Hungarica 46:235-245

Turlings TCJ, Erb M (2018) Tritrophic interactions mediated by herbivore-induced plant volatiles: Mechanisms,ecological relevance and application potential. Annu Rev Entomol 63:433-452

Wadhams LJ (1990) The use of coupled gas chromatography: electrophysiological techniques in the identification of insect pheromones, in Chromatography and isolation of insect hormones and pheromones, ed. by McCaffery AR and Wilson ID. Plenum Press, New York/London, 289-298

Wall C (1989) Evaluation and use of behaviour-modifying chemicals. In: Jutsum AR, Gordon RFS (eds) Insect pheromones in plant protection. Wiley, Chicester, pp 39-60

Wang P, Zhang N, Zhou L, Sheng-Yun S, Lei C, Hui A, Wang X (2014) Antennal and behavioral responses of female Maruca vitrata to the floral volatiles of Vigna unguiculata and Lablab purpureus. Entomol Exp Appl 152:248-257

Zangerl AR, Berenbaum MR (2009) Effects of florivory on floral volatile emissions and pollination success in the wild parsnip. ArthropodPlant Inter 3:181-191 